\title{
Buddhist Approaches to Impermanence: Phenomenal and Naumenal
}

\author{
Pradeep P. Gokhale
}

check for updates

Citation: Gokhale, Pradeep P. 2021.

Buddhist Approaches to Impermanence: Phenomenal and Naumenal. Religions 12: 1081. https://doi.org/10.3390/rel 12121081

Academic Editor: David

Peter Lawrence

Received: 27 October 2021

Accepted: 2 December 2021

Published: 8 December 2021

Publisher's Note: MDPI stays neutral with regard to jurisdictional claims in published maps and institutional affiliations.

Copyright: (C) 2021 by the author. Licensee MDPI, Basel, Switzerland. This article is an open access article distributed under the terms and conditions of the Creative Commons Attribution (CC BY) license (https:/ / creativecommons.org/licenses/by/ $4.0 /)$.
Department of Pali and Buddhist Studies, Savitribai Phule Pune University, Pune 411007, India; pradeepgokhale53@gmail.com

\begin{abstract}
The doctrine of impermanence can be called the most salient feature of the Buddha's teaching. The early Buddhist doctrine of impermanence can be understood in four different but interrelated contexts: Buddha's empiricism, the notion of conditioned/constituted objects, the idea of dependent arising, and the practical context of suffering and emancipation. While asserting the impermanence of all phenomena, the Buddha was silent on the questions of the so-called transcendent entities and truths. Moreover, though the Buddha described Nibbāṇa/Nirvāna as a 'deathless state' ('amatam padam'), it does not imply eternality in a metaphysical sense. Whereas the early Buddhist approach to impermanence can be called 'phenomenal', the post-Buddhist approach was concerned with naumena (things in themselves). Hence, Sarvāstivāda (along with Pudgalavāda) is marked by absolutism in the form of the doctrines of substantial continuity, atomism, momentariness, and personalism. The paper also deals with the approaches to impermanence of Dharmakirti and Nāgārjuna, which can be called naumenal rather than strictly phenomenal. For Dharmakīrti, noneternality was in fact momentariness and it was not a matter of experience but derivable conceptually or analytically from the concept of real. Nāgārjuna stood not for impermanence, but emptiness (śūnyat $\bar{a})$, the concept which transcended both impermanence and permanence, substantiality and non-substantiality.
\end{abstract}

Keywords: impermanence; momentariness; naumenal; phenomenal; absolutism; dependent arising; unanswered questions; Nibbāṇa

\section{Introduction}

In this paper, I want to show that though Buddhism is known for its doctrine of impermanence, the Buddhist approach to impermanence underwent change. The Buddha's approach can be called phenomenal (or phenomena-oriented). He said that all phenomena, that is, appearances or experiential objects, are impermanent. They arise from causes and cease. The real things beyond appearances are either non-existent or worth bracketing because they are irrelevant to the problem of suffering. The ontological and metaphysical issues which the Buddha set aside were regarded as important by the later Buddhists. As a result, we have reality-oriented approaches, which can be called naumenal (or naumenaoriented) approaches to impermanence. I have referred to three approaches of the latter kind in this paper. One was the approach of Sarvāstivāda (along with Pudgala-vāda); the other two are found in the positions of Dharmakīrti and Nāgārjuna. Though chronologically Nāgārjuna precedes Dharmakīrti, I have discussed the former at the end, as he deviates from the Buddha's approach to impermanence most.

\section{Part I: The Phenomenal Approach of Early Buddhism}

The doctrine of impermanence can be called the most salient feature of the Buddha's teaching. The significant presence of the doctrine can be observed from the first sermon to his last message before Parinibbanna. The first sermon of the Buddha centers on the problem of suffering and the middle path. However, interestingly, as is said in the Dhammacakkappavattanasutta, immediately after the Buddha's first sermon, one of the disciples, Koṇ̣añna, 
got an insight, which he expressed as, "Whatever has the nature of arising, has the nature of cessation".1

In the second sermon (Anattalakkhanasutta), the Buddha argued that the notions of 'I', 'mine', or 'self $(a t t \bar{a})$ ' cannot be attributed to the five aggregates. Impermanence of all the five aggregates is one of the grounds of the argument there. The argument has the following form:

1. Given any aggregate, it is impermanent.

2. Whatever is impermanent is unsatisfactory.

3. What is impermanent and unsatisfactory, is not fit to be regarded thus: 'This is mine; this is I; this is my self'

In fact, it can be said that among the three characteristics of things ('tilakkhana' (Pali), 'trilakșana' (Sanskrit)), namely impermanence (anicca), soullessness/non-substantiality (anatta), and un-satisfactoriness (dukkha), which the Buddha talked about, impermanence is the basis of the other two characteristics.

According to Vinaya, what Assaji told to Sāriputta and the latter to Moggalāna as the essence of the Buddha's teaching was the following:

The Tathāgata has expounded the causes

Of whatever be the phenomena that arise from causes.

He has also expounded their cessation;

This is what the great recluse has said. ${ }^{2}$

The last words of the Buddha before his Parinibbāna were as follows: "Now, monks, I exhort you, All conditioned things are subject to decay! Strive with diligence!"3

\subsection{Three Contexts of Impermanence}

The doctrine of impermanence in early Buddhism can be studied in four different but interrelated contexts:

1. The context of empiricism;

2. The context of conditioned/constituted objects;

3. The context of causes and conditions: Dependent arising;

4. The practical context of suffering and emancipation.

\subsubsection{The Context of Empiricism}

The Buddha was concerned with the nature of dhammas, that is, phenomena or empirical objects. ${ }^{4}$ When the Buddha was talking about 'all' in the context of the three characteristics, he was talking about the five aggregates. The five aggregates are nothing but material and mental aspects of a living being which are experiential in nature. Hence, Buddha's talk of impermanence had this context of empirical world and life. The Buddha was critical about the transcendental metaphysics of Upanisads, which accepted eternal brahman as the ultimate reality. His main objection was that nobody has seen Brahman face to face, but still the Upanișadic thinkers accept its existence dogmatically. The Buddha was also critical about the transcendental dogmatic beliefs of other schools, such as Jainism and Ājīvakas. ${ }^{5}$ His insistence on the empirical world is also reflected in his deliberate silence over the metaphysical issues put forward by his disciples, such as Vacchagotta and Mālunikyaputta.

\subsubsection{The Context of Conditioned/Constituted Objects}

Different formulae of the Buddha's doctrine of impermanence indicate that he was talking about the regular relation between origination and destruction. 'Udaya-vyaya', 'utpāda (Pāli: uppāda)-vyaya) are the pairs often found described as the characteristics of phenomena. "Whatever has the nature of arising, has the nature of cessation" ('yam samudyadhammam tam nirodhadhammam') and "All conditioned objects are impermanent" ('sabbe sańkhārā aniccā') are some of the major formulations of the doctrine of 
impermanence. These formulae come as the general rules based on observation and inductive generalization.

\subsubsection{The Context of Causes and Conditions: Dependent Arising}

An important contextual framework in which the Buddha presented his doctrine of impermanence is the framework of causes and conditions. The same framework also becomes a part of a larger framework of the doctrine of dependent arising. According to this framework, things arise as a part of a causal process. A thing/phenomenon arises from its causes and conditions (hetu-paccaya) and it ceases when they cease. The model of causation is a model of dependence. 'A thing arises from its causes' means that the existence of the thing depends on the causes. Moreover, because existence of the thing is dependent on its causes, it does not stay permanently; it ceases when the causes cease. The Buddha applies this model to the problem of suffering. Suffering arises from its cause, namely craving, and it will cease to exist when craving ceases. Hence, the Buddha presented the twelve-linked chain of causes and effects (dvādaśa-nidāna) in both forward (anuloma) and backward (pratiloma) direction. It explains how suffering arises and also how it ceases. ${ }^{6}$ This brings us to the practical context of the doctrine of impermanence.

\subsubsection{The Practical Context of Suffering and Emancipation}

The Buddhist doctrine of impermanence is not only an empirical and factual doctrine, but it has practical relevance for the issue of suffering and emancipation. We have seen that according to the Buddha's doctrine of three characteristics, the phenomena are impermanent, non-substantial and unsatisfactory and that impermanence is the basis of the other two features. Though the phenomena are in fact impermanent, due to avijja (ignorance or misconception) we think them to be permanent and develop craving (attachment or hatred) towards them and this causes suffering. In order to get rid of suffering one has to be free from misconception. It means developing right vision, which implies understanding things as they are, that is understanding them to be impermanent, non-substantial and unsatisfactory. Hence, realization of impermanence becomes an important part of the Buddhist meditation, particularly mindfulness meditation or insight meditation.

\subsection{Unanswered Questions and the Nature of Nibbāna}

It is suggested above that in his discussion of the problem of suffering and emancipation, the Buddha was primarily and solely concerned with the empirical world and not with the trans-empirical metaphysical issues. This becomes evident from the Buddha's silence on the metaphysical questions which are popularly known as un-answered questions (avyākrta-praśnas). The questions included the following:

(1) Is the world (loka) eternal or non-eternal?

(2) Is the world infinite or finite?

(3) Does the Tathaggata exist after death?

(4) Is the self (jiva) same as body or different from body? ${ }^{7}$

The list of these questions is further augmented by conjunctively affirming and denying some of the internal options and is made into the list of 12 or 14 questions. Here, it is to be noted that questions (1) and (2) do not pertain to this or that phenomenon in the world but to the world as a whole. This is important, because the Buddha did make statements about phenomena in the world by saying that they arise from causes and whatever so arises also comes to an end. The world as a whole can be conceived as the totality of the series of causally connected phenomena, and now the question is whether this totality has a beginning and an end. Similarly, it is generally agreed that the Buddha accepted the doctrine of rebirth and the wheel of becoming caused by misconception (avidya) and craving $(\operatorname{trṣnn} \bar{a})$, but the question was whether the person such as Tathāgata, who is free from these causes of suffering, will also have rebirth. Similarly, it was clear that the Buddha did not accept a noumenal self, i.e., ātman, but the question was whether the phenomenal 
self, which he accepted was inseparable or separable from body. The Buddha's silence on these questions has been explained in different ways.

One possible explanation which we find in the suttas, such as Cülamalunikyasutta (Warren 1953, pp. 117-22) and Potthapadasutta (Humphreys 1987, pp. 53-54), is that these questions and the possible affirmative or negative answers to them are irrelevant to the fundamental problem of life. They are similar to the questions regarding the physical and social details of a poisoned arrow for the person who is actually wounded with it. The other explanation is found in Aggivacchagottasutta (Warren 1953, pp. 123-28), which particularly refers to the question regarding the existence of Tathaggata after death. The Buddha claims there that the question is a false question, i.e., the question based on a false presupposition. It is similar to regarding an extinguished fire and questioning whether it went in eastern direction or western direction, etc. It is doubtful whether this second explanation given by the Buddha was logically satisfactory. The question regarding extinct fire (whether it went in the eastern direction or western direction, etc.) is a wrong question based on a false presupposition that fire, when it becomes extinct, goes somewhere. No such false presupposition is logically involved in the question about Tathaggata.

The question whether the self (jiva) and body are the same or different is an equally tricky question. The Buddha, in a dialogue with Ananda, said that if he would have said to Vacchagotta that there is a self (other than body), then it would have been a siding-in with eternalists (who believed that there is the eternal atman), and if he would have said that the self does not exist, it would have been siding-in with annihilationists. ${ }^{8}$ The question is very much related with the question of existence of Tathāgata after death. Perhaps the Buddha is reading the question the way he does to avoid the disrespect people would have shown to the doctrine of nibbanna if the Buddha would have plainly accepted that a liberated person no longer exists after death. This leads us to the question of interpreting Buddha's description of nibbāna.

The Buddha's description of nibbāna as non-constituted (asankhata) and a deathless state (amatam padam) has been interpreted as Buddha's acceptance of nibbāna as eternal. ${ }^{9}$ It can be argued that there is a basic difference between the so-called deathlessness of soul or Brahman on the one hand and that of nibbanna on the other. The soul or Brahman are supposed to be real positive entities, whereas ontologically, nibbanna is of the nature of nirodha (cessation, stoppage), which is negative in nature. Cessation of anything is eternal in a peculiar sense. It occurs at a particular time, but after that, it remains forever. There is no cessation of cessation. ${ }^{10}$ It can also be called non-constituted, because, being of the nature of negation, it is not made or constituted in the way any positive entity is. This does not mean that nirodha or nibbāna should be regarded as eternal in the sense of non-temporal. As with any cessation or destruction of a thing, it does occur at a point of time. Nibbanna in Buddhism is regarded as the cessation of cravings and subsequently the cessation of pains. Since this occurs in a human being, it also has a psychological aspect. From a psychological point of view, it is described as the highest satisfaction (paramam sukham). In Udānavagga it is described as follows:

"Whatever is the sensuous pleasure or the great heavenly pleasure, it does not amount even to the sixteenth part of the pleasure arising from the destruction of craving"11

Thus, the realization of nibbanna is not that of a positive and eternal ontological entity like Ātman-Brahman of the Vedāntins. The point I want to make is that the Buddha's general theory of impermanence of all phenomena, of all that is constituted, etc. does not get violated by his conception of nibbanna as deathless and non-constituted. That is because the theory of impermanence applies to positive phenomena, whereas nibbanna, which is conceived as cessation of cravings, cessation of suffering or that of perception and sensation ('samjiña-vedayita-nirodha), is essentially negative in nature. However, Nibbāna is not cessation of awareness, and psychologically, it is 'satisfactory'. 


\section{Part II: Naumenal Approaches of Later Buddhism}

\subsection{From Empiricism to Absolutism: Post-Buddha Developments}

After the demise of the Buddha, some followers attempted to give substantial basis to the Buddha's phenomenological thought. These attempts manifest what Kalupahana (2011, p. 125) calls 'absolutist tendencies after the Buddha's demise'. Such tendencies are found as a part of Sarvāstivāda and also outside it.

\subsubsection{Realism (Sarvāstivāda)}

Sarvāstivādins maintained that everything exists at all times. Hence, how to account for change along with continuity was a problem for them. According to them, dravya (svabhāva) of a thing does not undergo change (Dhammajoti 2009, p. 134). What changes then? Dharmatrāta held that only the manner or mode of being (bhava) changes; Ghoșaka held that only a characteristic (lakșana) changes; Vasumitra held that only the state of the thing $(a v a s t h \bar{a})$ changes; Buddhadeva held that only the temporal relation changes ('anyathānyathātva'). (Ibid., p. 119) Among these views, Vasubandhu equates Dharmatrāta's view with the parināmavāda of Sānkhya. He approves of Vasumitra's view which describes change in terms of activity (kāritra). ${ }^{12}$ (AKB 1967, V.26). Other views can be compared with those of Jainas and Nyāya-Vaiśeșikas. ${ }^{13}$

\subsubsection{Atomism}

Vaibhāșikas also advocated atomism. Samghabhadra defined an atom (paramānu) as 'The finest part in a resistant matter which cannot be further divided.' He also introduced the notion of an aggregate atom (sanghäta-paramānu), which is 'a multitude of such paramānu-s that are mutually combined and necessarily inseparable.' Dhammajoti observes that this gives us two types of paramānu: "(1) paramānu in the proper sense of the term - the smallest conceivable building block of matter. This is also called dravyaparamānu. (2) samghāta-paramānu in the sense of a molecule ${ }^{14}$ that can actually occur in the phenomenal world". (Dhammajoti 2009, p. 200). Out of them, sanghhāta-paramānu can be called empirical, but dravya-paramānu is supposed to be transcendent. In this, it resembles the paramānu of Vaiśeșikas. In fact, the paramānu of Vaibhāsikas is supposed to be so minute that it occupies no space. Secondly, unlike the paramānu of Vaiśeșikas, the paramānu (even dravya-paramānu) of Vaibhāṣikas is supposed to be impermanent, rather momentary.

\subsubsection{The Doctrine of Moment (Kṣaṇa)}

Sanghabhadra in Nyāyānusāra, while defining paramānu as the ultimately small particle of matter, also defined moment ( $k s a n a)$ as the smallest unit of time (Dhammajoti 2009, p. 200). Von Rospatt (1995, pp. 29-39) discusses how the doctrine of momentariness was accepted in various ways in Hīnayāna schools of Buddhism. Reducing impermanence to momentariness can be regarded as attempt to absolutize impermanence. We will see later that the doctrine of momentariness became a central point of Dharmakīrti's ontology.

\subsubsection{Personalism (Pudgalavāda)}

We have seen that in early Buddhism, all the five aggregates were regarded as impermanent and non-substantial. Accordingly, whom we regard as a person is just a collection of the five aggregates. However, the question then was how to understand unity or continuity between action and fruition, transmigration and emancipation. Those Buddhists, who by their sect were called VātsīputrĪyas and Sāmmitīyas, held that a person who represents such unity and continuity must be real. "In the true and absolute sense, the person (pudgala) is perceivable, realisable, exists and is well-observed. Hence, there is definitely the pudgala" (Dhammajoti 2009, p. 91). To avoid the charge of eternality and momentariness, they regarded the person as "neither identical nor different from the aggregates" (Bronkhorst 2009, p. 69). This indicates the tendency to essentialize a person within the Buddhist framework of the 'no soul' doctrine. Other Buddhist sects were opposed to it, as they regarded 'person' as a mere designation, not a real entity. 


\subsubsection{Transcendentalism (Lokātītavāda)}

We have seen that the Buddha observed silence over the question whether the Tathāgata exists after death. His answer to the question of the eternality of nirvāna was more pragmatic than theoretical. Sarvāstivādins, in their systematization, brought nirvāna under the category of asamskrta-dharma (unconditioned or un-constituted thing), which they regarded as eternal. A similar eternalist tendency viewed "the Buddha as someone who has totally transcended the world and nirvāna as a state of eternal life after death" (Kalupahana 2011, p. 129).

\subsection{From Empirical to Conceptual: Dharmakìrti}

Around the second century AD, Nyāyasūtra of Akṣapāda presented its framework of pramāna (means to knowledge) and prameya (object of knowledge) and posed a challenge before different philosophical perspectives to fit themselves in the pramāna-prameya framework. Different perspectives, such as Sāṅkhya, Jainism, Mīmāṃsā, and Vedānta, responded to this challenge by developing their own pramanna-prameya frameworks.

Buddhism had a two-fold response to this challenge. Nāgārjuna posed a counterchallenge before Nyāya through his works Vaidalyaprakarana and Vigrahavyāvartanī, where he questioned the pramāna system as such. The Buddhist philosophers Dinnāga and Dharmakinti followed a different route. They developed an alternative pramāna system suitable to the non-eternalist and non-substantialist ontology of Buddhism. In the next section, we will deal with Nāgārjuna's approach to impermanence. In this section, we will deal with the approaches of Dinnāga and Dharmakīrti, particularly that of the latter.

Dinnāga-Dharmakirti epistemology is marked by the acceptance of two (and only two) pramānas, perception and inference. Among them, impermanence of things is a matter of inference. An often-quoted example of inference in their system is that a word is impermanent because it is a product. The example contains a general statement, such as "Whatever is a product is impermanent like a pot"; such statements echo the Buddha's pronouncement of the impermanence as the property of all that have origination. However, the ways in which such general statements-technically called the statements of pervasion (vyāpti)—occur in Dinnāga's and Dharmakīrti's models of inference are different. In Dinnāga's theory of inference, the statement of pervasion occurs as the one based on observation and non-observation. It is closer to the Buddha's approach to impermanence in this respect. However, Diñnāga's theory of inference does not give the notion of pervasion as a universal relation between probans and probandum. According to his theory of triple character (trairūpya) of probans, positive concomitance (anvaya) is obtained in the realm of similar cases (sapakșa) and negative concomitance is obtained in the realm of dissimilar cases (vipakșa). However, the two concomitances together do not give a 'universal concomitance' belonging to all possible realms. Dharmakīrti, however, interpreted the doctrine of triple character as implying universal concomitance between probans and probandum. ${ }^{15}$ This universal concomitance according to him cannot be ascertained through observation and non-observation, but through necessity. On the basis of necessity, we are able to say that if probans exists, probandum must exist and that probans cannot exist in the absence of probandum. This necessity according to him becomes available in two ways: 1 . Causeeffect relation, such that we can say that if an effect exists, it must have been preceded by its cause. Here, the effect serves as the probans, which is called ' $k \bar{a} r y a-h e t u$ '. 2. Identity between two aspects of one and the same thing, such that we can say that if one aspect (that is, the pervaded aspect) exists, the other aspect (that is, the pervading aspect) must exist. Here, the pervaded aspect is supposed to be the probans, which is called svabhāvahetu. ${ }^{16}$ All this is relevant to the doctrine of impermanence because Dharmakirti discusses the doctrine of impermanence in the context the inference based on svabhāva-hetu. "Whatever is real is impermanent" occurs as a statement of pervasion in the context of svabhāvahetu in Nyāyabindu. In Hetubindu, Dharmakīrti argues for a more radical form of the doctrine of impermanence, as the doctrine of momentariness of everything that is real (sat). 
Dharmakīrti in Hetubindu argues for the statement of pervasion, "Whatever is real is momentary", on the basis of the identity relation between 'being real' and 'being momentary'. While justifying this pervasion, Dharmakīrti defines real (sat) as 'capable of a causal function' (arthakryāsamartha). He then argues that a non-momentary thing does not have capacity with respect to anything, because it lacks the capacity to produce an effect either successively or simultaneously. ${ }^{17}$

It is important to note that the pervasion relation between 'real' and 'momentary' is not known through observation and non-observation, but on the basis of the conceptual relation between 'being real' and 'being momentary' (technically, it is called the identity (tādatmya) relation, but I have argued elsewhere (Gokhale 2018) that it can be regarded as the relation of conceptual or analytic necessity ${ }^{18}$ ). Such a conceptual relation becomes possible because of the particular definition of the term real (sat). Dharmakīrti defines real (sat) as 'capable of a causal function'(arthakriyassamartha). This would not have been possible if the term 'sat' would have been defined differently. It is interesting to see how different metaphysical schools define the notion of 'real' differently and derive different implications from them. For example, Advaita-Vedāntins defined sat as that which is never sublated $^{19}$ and argued on this basis that what is real must be eternal and only Brahman is real in the strict sense of the term. Jainas defined sat as that which has origination, destruction as well as stability ${ }^{20}$ and tried to establish their theory of non-absolutism in the light of this definition of sat. Nyāya-Vaiśeșikas distinguished between being (astitva) and realness (sattā). According to them, 'being' ${ }^{21}$ characterizes all the seven categories (padārthas), whereas realness (sattā) is a universal property (sāmānya or jāti) which characterizes only three categories, ${ }^{22}$ i.e., substance, quality, and motion. The point is that Dharmakīrt's claim that everything real is momentary is not a purely observational truth. It is not only analytical, but also governed by a particular definition of 'real' ${ }^{23}$ In his work Nyāyabindu, Dharmakīrti's example of pervasion in the inference from 'own-nature as probans' (svabhāvahetu) is "All that is real is impermanent like a pot etc.". He calls this probans ('realness') as 'pure own-nature as probans' ('śuddhasvabhāvahetu'). He also considers two other statements of pervasion: "All that is originated is impermanent" and "All that is made is impermanent". He calls the probans namely originated-ness (utpattimattva) as 'a different natural property' ('svabhāvabhūtadharmabheda') and 'made-ness' as an adjunct property ('upādhibheda') This suggests Dharmakīrti attaches primary status to 'realness', and secondary status to originated-ness and still more secondary status to 'made-ness'. The reason for this seems to be that realness (which is defined as the capacity to have a causal function) implies impermanence more directly, whereas originated-ness or 'made-ness' does not imply impermanence so directly. They do so only via realness. ${ }^{24}$

If we go back to the Buddha's doctrine of impermanence, we find that 'realness' has no status in the Buddha's original version of the doctrine. On the other hand, 'originated-ness' has a primary status there. Hence, Dharmakīrti's approach, which understands impermanence as momentariness and derives it inferentially and conceptually from 'realness', is essentially different form Buddha's approach, which holds that 'everything originated is subject to destruction' as an empirical and inductive truth.

The difference between anitya and kșanika is quite important. 'Kșanika' means that which gets destroyed 'immediately'. As Von Rospatt (1995, p. 1) put it, the fundamental proposition of the doctrine of momentariness is that "all phenomena ... . Pass out of existence as soon as they have originated and in this sense are momentary". 25 'Anitya' means that which will get destroyed sometime (not necessarily immediately); that everything which is constituted from causes ceases to exist some time can be a matter of experience or an inductive generalization derived from the common human experience. Certain things are experienced by us as moving fast or instantly changing. For instance, lightning, a flowing river, a vehicle, or an animal running fast. However, not every object of common experience is observed to be changing every moment in this sense, nor can it be derived to be so by a simple inductive generalization. The Buddha's appeal was to the sense of anityat $\bar{a}$, which was realizable by many through careful and unattached observation of the 
facts of life. His appeal was not to the intellectual insight into momentariness, which was available to few. ${ }^{26}$

Does the doctrine of momentariness score over the early Buddhist doctrine of impermanence, in terms of its emancipatory potential? It seems that it does not. ${ }^{27}$ If we suppose that everything that is real in fact changes every moment, on the basis of an inferential exercise, it remains an intellectual belief and not a matter of experience. In mindfulness meditation, the phenomenon we experience from moment to moment may be changing or continuous and stable. One observes that even what appears as stable is not permanently stable. One does not experience it to be changing every moment. Experience of 'impermanence' is more relevant to emancipation than an intellectual belief in momentariness.

Dharmakīrt's deviation from the Buddha's original view can be compensated by the former's conception of the unique particular (svalakșana), as the object of perception and as ultimately real (paramārtha-sat). However, Dharmakīrti's view still remains naumenal, as it holds that the phenomenon itself is the naumenon. It is distinct from the Buddha's approach, which focused on the phenomena, but was silent about the so-called naumena.

\subsection{Beyond Permanence and Impermanence: Nāgārjuna}

Was Nāgārjuna true to the Buddha's original teaching? Some scholars of Theravāda Buddhism have claimed that he was. For example, Gombrich (2011, p. 37) believes that Nāgārjuna's reaction against the essentialism of Buddhist Abhidhamma was in the spirit of the Buddha's intention. David Kalupahana (2011, pp. 163-66), in his writings, emphasized the continuity between early Buddhism and Nāgārjuna's Mādhyamika philosophy. He interpreted Nāgārjuna's position as non-substantialism (nairātmya of dharmas as well as pudgala). He equated in this context àtman with svabhāva and consequently nairātmya, with nihsvabhāvatā or śūnyatā. He also referred to Kātyāyanāvavāäasūtra, which Nāgārjuna himself refers to as evidence for Buddha's non-essentialist approach. Moreover, Kalupahana regards dependent arising (pratītyasamutpāda) as common to both early Buddhist philosophy and Nāgārjuna's position. It is doubtful whether these evidences are sufficiently convincing.

\subsubsection{Impermanence, Non-Substantiality, and Essence-Less-Ness}

It is well-known that the Buddha denied the eternal substance. However, whether Kalupahana is justified in identifying non-substantiality (nairätmya) with essence-less-ness (nihsvabhāvatā) is doubtful; neither in early Buddhism nor in Nāgārjuna do we find such identification. The Buddha said that conditioned things are impermanent, non-substantial, and unsatisfactory by their very nature (lakșana).$^{28}$ This can be called the non-essentialist approach of the Buddha in the sense that it rejects any permanent essence of things. However, it accepts impermanence itself as an essence of things and in this minimal sense, the Buddha's approach can be called a form of minimal essentialism. Nāgārjuna argues against essentialism even in its minimal form.

In chapter 18 (Ātmaparīkșa) of MMK, Nāgārjuna critically examined the notion of self by arguing that it can be neither identical nor different from aggregates (skandha). However, Nāgārjuna's denial of the self differs from that of early Buddhism in at least two ways:

1. In the early Buddhist model, the notion of aggregates is primary. It is not doubted that the aggregates are real; they are only argued as impermanent, non-self, and unsatisfactory. Nāgārjuna, on the other hand, denied the very existence of the five aggregates in chapter 4 (Skandhaparīks $\bar{a})$ of MMK.

2. In chapter 18 verse 6, Nāgārjuna says, "Buddhas have conveyed that there is self. They have also taught that there is "nonself". They taught as well that there is neither self nor non-self". This suggests that the truth (that is, śūnyatā) according to the Buddha, as Nāgārjuna understood it, is beyond Self and Non-self.

The chapter 23 (Viparyāsaparīkșā) of MMK is also relevant in this context. Here, Nāgārjuna examined the notion of perversion (viparyāsa). According to traditional Bud- 
dhism, the defilements (kleśas) arise due to four types of perversions, which constitute the identification of non-substantial as substantial, impermanent as permanent, unsatisfactory as satisfactory, and impure as pure. It is understood there that the empirical objects are in fact non-substantial, impermanent, unsatisfactory, and impure, but they are thought to be otherwise due to misconception (avidyā). Nāgārjuna in the chapter 'Viparyāsaparīkșa' ' questions the very possibility of the four perversions. Let us consider some of his statements:

"Neither the existence nor the nonexistence of the self is established in any way. How will the existence or nonexistence of the defilements be established without that?" (MMK, 23.3); ${ }^{29}$

"The perversions concerning the good and the bad do not occur essentially; in dependence on what perversion concerning the good and the bad will there be defilements then?" (23.6); ${ }^{30}$

"If it would be a perversion to think with respect to impermanent things that they are permanent, how can there be a perversion then, there being nothing that is impermanent with regard to what is empty?" (23.13) ${ }^{31}$

"If to think with respect to impermanent things that they are permanent is a perversion, then, isn't it a perversion to think with respect to empty things that they, are impermanent?" $(23.14)^{32}$

The above statements suggest that emptiness (śunnyatā) becomes the major overarching concept in Nāgārjuna's scheme. It treats 'pure and impure', 'substantial and non-substantial', and 'permanent and impermanent' as binaries worthy of rejection from both sides.

In fact, Nāgārjuna deconstructs the traditional Buddhist doctrine of impermanence in different ways:

1. As we have seen, the content of the Buddha's teaching is famously described by the following verse:

"The Tathāgata has expounded the causes of whatever be the phenomena that arise from causes. He has also expounded their cessation; This is what the great recluse has said".(See Note No. 2)

Opposed to this, Nāgārjuna, in the first chapter of MMK, denied the very possibility that things can arise from causes. In fact, he denies 'arising' as such when he says, "Not from itself, not from another, not from both, nor without cause: Never in any way is there any existing thing that has arisen". ${ }^{33}$

2. A basic formulation of the rule of impermanence according to early Buddhism is that whatever is characterized by origination, is characterized by cessation ("yat samudayadharmam tat nirodha-dharmam"). This implies that in fact there are things which have origination and destruction. According to Nāgārjuna, on the other hand, things have no origination at all. Thus, he argues, when origination is denied, cessation automatically gets denied. ${ }^{34}$

3. In chapter 7 (Samskrta-parīkșā), Nāgārjuna examined the definition of a conditioned thing as that which has origination, stability, and destruction (utpäda-sthiti-bhanga) and denies all three with many arguments.

4. In Chapter 15 (Svabhāvaparīkșā), Nāgārjuna considered eternality (śâśvatatva) as an undesirable consequence (MMK, 15.11b). However, he also denied change (being otherwise, 'anyathātva'). ${ }^{35}$

5. Nāgārjuna devoted the whole chapter 21 (Sambhavavibhavaparìkșā) to the critical examination (and subsequent rejection) of both arising and dissolution and also of transmigration (series of births, 'bhavasantati'). The above evidences show how Nāgārjuna's position is in favor of the non-essentiality of everything, rather than impermanence and change characterized by origination and destruction as the nature 
of reality. In fact, Nāgārjuna seems to be arguing that non-essentiality is the Buddha's original position, rather than impermanence or non-substantiality.

\subsubsection{Kātyāyanāvavāda-Sūtra}

In support of his position, Nāgārjuna refers to Kātyāyanāvavāda-sūtra of the Buddhist canons, where the Buddha denies both existence and non-existence. ${ }^{36}$ Candrakīrti, the commentator, quotes from the Kātyāyanāvavōada-sütra:

"This world is not liberated, Oh Kātyāyana, because it dogmatically adheres very much to existence or non-existence, ..." $" 37$

In this dialogue, the Buddha is talking about dogmatic adherence (abhiniveśa) to existence and non-existence as the cause of bondage. There is no explanation of the problem about existence and non-existence. We find an explanation of it in the Pāli analogue of the sutta, viz. Kaccānagottasutta of Saṃuttanikāya:

“... Venerable sir, they say, right view right view. In what way is there right view?" "The world in general, Kaccāna, inclines to two views, to existence and to non-existence. But when one sees with right discernment the things in the world as they actually originate, 'non-existence' with reference to the world does not occur to one. And when one sees with right discernment the cessation of the things in the world as they actually take place, 'existence' with reference to the world does not occur to one.

It is in this way, Kaccāna, that there is right view. 'All exists', Kaccāna, is one extreme. 'All does not exist' is the second extreme. Avoiding these two extremes, the Realized One teaches Dhamma by the middle way ... "38

Here, the Buddha is explaining how we cannot focus on existence or non-existence of a changing thing. A changing thing is that which has origination and cessation. However, if we focus on its origination, we cannot say that it is non-existent; and if we focus on its cessation, we cannot say that it is existent. In other words, a changing thing is not existent in the sense of permanent existence, nor is it non-existent in the sense of absolute nonexistence. Nāgārjuna, however, seems to interpret the Buddha's argument differently. The Buddha in this sutta was denying existence and non-existence in the context of origination and cessation of changing things, whereas Nāgārjuna is denying them context-freely. The Buddha was expounding the dialectics of change, whereas Nāgārjuna is denying existence and non-existence along with change.

\subsubsection{Argument from Dependent Arising}

Lastly, it is often argued that Nāgājuna's Mādhyamika philosophy is continuous with early Buddhism, because the doctrine of dependent arising ('pratityasamutpāda') has a central position in both. The fact is that though the notion of dependent arising is accepted as central in both, it means two different things in the two contexts. 'Dependence' in the early Buddhist concept of 'dependent arising' is causal dependence. It refers to arising of any phenomenon from its causes and conditions. In Nāgārjuna's philosophy, however, it does not mean causal dependence. In the first chapter and many other chapters, Nāgārjua criticized the cause-effect relation from different angles. ${ }^{39}$ He gives a more basic formula, according to which whatever arises depending upon anything, does not arise essentially. ${ }^{40}$ Any dependence for him, causal or otherwise, implies non-essentiality. Hence, Candrakīrti interprets the term pratitya ('depending upon') as apeksya ('relative to'). ${ }^{41}$ and states as an example of the dependence relation, "The long arises depending upon the short". ${ }^{42}$ Obviously, though the notions of long and short are relative to each other, there is no causal relation between the two. 


\section{Conclusions}

I have tried to argue that the Buddha's approach to impermanence can be called 'phenomenal' in the sense that he was concerned with the objects of experience and not with what the things are in themselves independently of their empirical nature. The Buddha, while presenting the doctrine of impermanence, was not talking about the ideal or abstract nature of things. Even when he talked about Nirvāna, which was for him the state of cessation and the highest happiness, he did not treat it as a positive eternal entity such as the Brahman of Vedānta.

After the demise of the Buddha, many of his followers wanted answers to the questions which the Buddha had deliberately kept unanswered. Hence, we find a tendency to absolutize the early Buddhist concepts of dhamma/dharma (eternal svabhāva, paramānu), time (kṣana), nirvāna (asamskrta-dharma), and so on. Dharmakīrti, the Buddhist epistemologist, transformed the Buddha's doctrine of impermanence into the radical thesis that every real thing is momentary. Whereas Buddha's doctrine of impermanence was empirical or inductive, Dharmakīrti's doctrine of momentariness is more conceptual and abstract.

With regard to Nāgārjuna, I have suggested that while criticizing the Sarvāstivādin's doctrine of 'svabhāva', he went to the other extreme by denying every svabhāva and advocating nihsvabhāvatā or śünyatā of all things. This approach tries to transcend both permanence and impermanence. I have included it under the Naumenal approach insofar as it seeks for ultimate truth (paramārthatah satya) beyond the empirical existence.

A widely accepted view is that Nāgārjuna's arguments are not aimed at questioning early Buddhism as such, but they are aimed at refuting the essentialism (svabhāvavāda) of Sarvāstivādins. It is held that Nāgārjuna, through his non-essentialist arguments, carries forward and strengthens the non-essentialism of early Buddhism. I have presented a different view here.

I want to claim that the non-essentialism of early Buddhism and that of Nāgārjuna's Mādhyamika Buddhism are not of the same type. The position of early Buddhism can be called anti-eternalist, but not anti-essentialist in the strictest sense of the term. The doctrine of tilakkhana/ trilakșana, which asserts impermanence, non-substantiality, and un-satisfactoriness as the three characteristics of all conditioned things, implies that this is the own nature (svabhāva) of those things. This implies essentialism (svabhāvavāada) in its minimal sense. It is important to note that the right view (samma-ditthi) meant understanding the things as they are (yathābhüta-vastu-darśana), which included understanding impermanent things as impermanent. This can be called an essentialist understanding of empirical reality in its minimal sense. The essentialism involved in this can be called 'logicolinguistic' in the sense that while attributing properties to things one is not necessarily giving ontological status to the properties; however, one is following the rules of language such as the subject-predicate structure of sentences and the rules of logic such as identity, non-contradiction, and bivalence. ${ }^{43}$ In comparison to this logico-linguistic essentialism, the essentialism advocated by Sarvāstivādins and Pudgalavādins can be called ontological, as it gives an ontologically real status to the essences. ${ }^{44}$

Arguably, Nāgārjuna was critical about the essentialism of both these types: logicolinguistic and ontological. Although he made compromises with essentialism at the level of conventional truth (lokasamvrrti-satya), he advocated an extreme form of anti-essentialism at the level of the ultimate truth (paramārthatah satya).

Funding: The research received no external funding.

Institutional Review Board Statement: Not Applicable.

Informed Consent Statement: Not Applicable.

Data Availability Statement: Not Applicable.

Acknowledgments: I am grateful to the anonymous reviewers, whose comments on the earlier version of the paper helped me in updating and improving the quality of the paper. I also thank my 
colleagues and friends Lata Deokar, Daniel Stuart and Ashish Sangle, for helping me by providing soft copies of some important reference materials.

Conflicts of Interest: The author declares no conflict of interest.

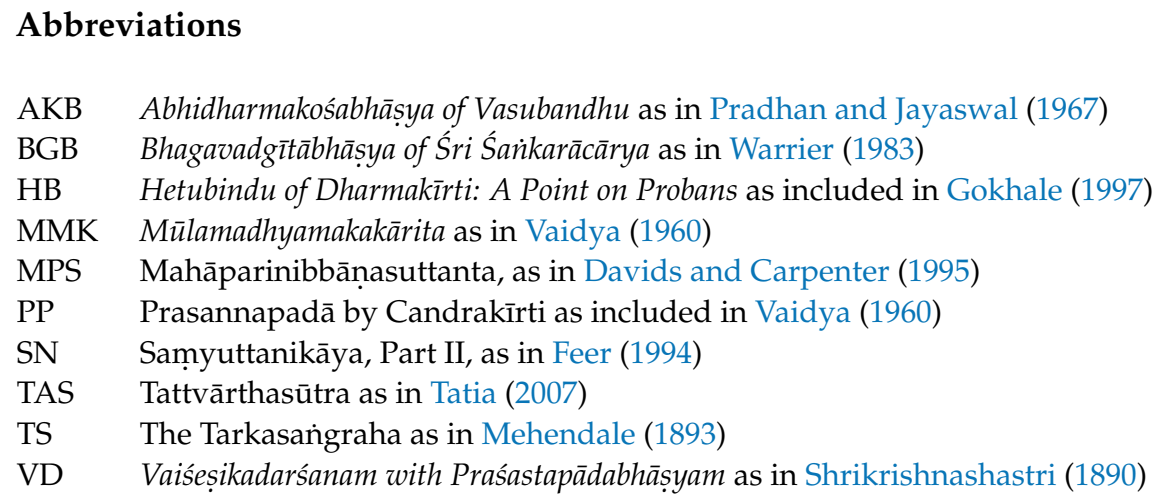

\section{Notes}

"yam samudayadhammaṃ, tam nirodhadhammaṃ" Mahāvagga (Oldenberg 1879, p. 11).

"Ye dhammā hetuppabhavā tesaṃ hetuṃ tathāgato āha | tesaṃ ca yo nirodho evaṃvādì mahāsamaṇo I I", Mahāvagga (Oldenberg 1879, p. 40).

"Handa dāni, bhikkhave, āmantayāmi vo, vayadhammā sañkhārā appamādena sampādethā"ti. MPS, p. 156.

Kalupahana (2011, p. 80) called Buddha a radical empiricist. Gombrich (2013, pp. 114-15) understood the five skandhas as the processes which are the constituents of experience.

5 As Kalupahana (2011, p. 53) put it, “Abandoning the search for ultimate objectivity, the Buddha had to renounce most explanations of reality presented by his predecessors. The Brahmanical notion of self (ātman), the Materialist and Ājīvika conceptions of nature (svabhāva) and even the Jaina theory of action (kiriya), appeared to him too metaphysical".

6 I think that for a proper understanding of the twelve-linked chain, links such as misconception (avijjā), formation (sankkhāra), consciousness (viñ̃̄aña), etc. up to suffering should be regarded not as objects or events but as tendencies or processes.

7 These questions were asked to the Buddha with minor variations in the suttas Aggivacchagottasutta, Cūlamalunkyasutta, and Potthapadasutta.

$8 \quad$ Humphreys (1987, pp. 54-55) (Based on Saṃyuttanikāya, Avyākatasamyyutta (XLIV), Section 10 called Ānando or Atthatto).

9 Walpola Rahula understood Nirvāna as the Truth which is beyond cause and effect. (cf. Gombrich 2013, p. 156). Gomrich disagreed with him for his use of the word 'Truth', which according to Gombrich should have been replaced by 'reality'. However, Gombrich, too, regarded Nirvāna as real and unconditioned, as something beyond experience and language. He explained Nirvāna as a mystical experience and suggested that the Buddha was influenced by Upanisads in this approach. I have tried to argue that these interpretations do not capture the so-called permanence of Nibbāna.

10 This idea was later on conceptualized by the Nyāya-Vaiśesika philosophers, when they discussed absence (abhāva) as a category. They accepted four types of absence: prior absence (absence of a thing before it is produced), destructional absence (absence of a thing subject to its destruction), absolute absence (unconnected-ness of a thing with another thing), and mutual absence (difference). Nirodha (cessation) of a thing is comparable with destructional absence. According to Nyāya-Vaiśeșikas, the destructional absence of a thing, as Annambhatta defines it, has a beginning, but no end. ("sādir anantah pradhvamsah", TS, p. 30). However, the major difference between the 'destructional absence' of Nyāya-Vaiśesikas and the nirodha of Buddhists is that the former is regarded as an ontological entity (padārtha, which exists), whereas Buddhists do not regard absence to be so.

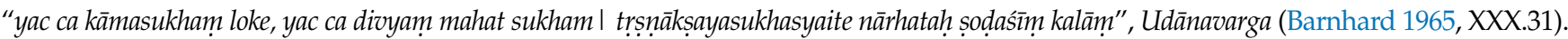
Dharmakīrti, in his theory of 'real as momentary', seemed to have developed the concept of kāritra into arthakryākāritva (causal efficacy).

13 Buddhadeva's view is understood as relativistic, which can be compared with the view of the Jainas. It can also be compared with the Nyāya-Vaiśeșika view, according to which a thing is described differently depending on the qualifying condition (viśeșaṇa or avacchedaka). Ghoșaka's view that some qualities of a changing thing are manifest (vyakta), whereas others remain latent (avyakta), can also be found in Sānkhya.

Lysenko (2016) was probably right in her disagreement with 'molecule' as the translation of the term 'sanghātaparamānu'. She understood sanghātaparamānu as a complex organic entity, incorporating the sense modality of its experiencing (sensibilia).

For my discussion of the doctrine of three constitutive elements of hetu as understood by Dinnāga and differently interpreted by Dharmakīrti, see Gokhale (1992, pp. 37-46, 87-90). 
16 The term svabhāva here means own nature or a natural aspect or an essential aspect of a thing. In the inference of this type, both probans and probandum are svabhāvas. The pervaded (vyāpya) svabhāva is probans and the pervader (vyāpaka) svabhāva is the probandum. Hayes (1987, p. 323) claimed that the expression "svabhâvahetu" should be analyzed as a saptami tatpurusa compound: "svabhâve hetur iti svabhāvahetuh". This is not necessary. Dharmakīrti describes both probans ('gamaka') and probandum ('gamya') as svabhāva as in (Pandeya 1989, 3.192cd-193ab) ("siddhah svabhāvo gamako vyāpakas tasya niścitah I I gamyah svabhāvas tasyāyam ... .").

"na caivā kṣaṇikasya kvacit kācit śaktir asti kramayaugapadyābhyām kāryakriyāśaktivirahāt", HB, p. 50. Dharmakīrti gave a detailed argument for momentariness in (HB, pp. 16-50). Dharmakīrt's method here was not empirical but that of conceptual analysis. This raises a doubt about Steinkellner's (1974, p. 127) claim: "we cannot but say that an inference from the concept of an essential property (svabhāvah) is as empirical as the inference from the concept of an effect(kāryam)".

18 Here, I differ from Steinkellner (1974), who in opposition to Stcherbatsky's suggestion that the inference based on svabhävahetu has an analytic character, argued that Dharmakinti, while establishing the necessity of the pervasion, refers to the identity between hetu and sädhya as essential properties, but does not refer to the containing relation between the two concepts. The following points need to be considered in this context: 1 . The object of inference is not a real particular object (svalaksana), but a conceptually constructed object which can be expressed by a word. Hence, even if 'svabhāva' as hetu is understood as 'essential property' as Steinkellner does, the essential property there is to be understood as a conceptual property. 2 . The identity (tādātmya) between the two essential properties, namely hetu and sädhya, is to be understood not as absolute, but qualified identity. Basically, it is unilateral and not bilateral. For example, every śimśapā, by its very nature, is a tree; however, every tree is not by its very nature a śimśapā. Hence, there is a containing relation between the two concepts, namely hetu and sādhya, where the hetu-concept is supposed to be pervaded by the sādhya-concept. 3. Moreover, the relation between them is supposed to be an internal relation as against the cause-effect relation, which is external. This is suggested by Dharmakīrti by the expression svasattāmātrabhāvin as the adjective of $s \bar{a} d h y a$ in the case of svabhāva-hetu, which suggests that sādhya can be derived from the very being of hetu. Hence, just saying that there is a factual identity between svabhāva-hetu and sādhya does not capture what Dharmakīrti wanted to say. 4. Lastly, Steinkellner considered for comparison only Kantian formulation of analyticity. We come across some other formulations also. Quinton (1964), for instance, discussed at least three formulations of analytic necessity (which is the necessity according to him), one of them being that "necessary truth depends on identity or repetition". The point is that analyticity should be considered in a wider perspective in order to appreciate Dharmakīrti's theory of svabhāvahetu better.

As Śankara said in his commentary on Bhagavadgitta 2.16 "The real is that the cognition of which does not deviate and unreal is that the cognition of which deviates. In this way, when the distinction between real and unreal is governed by cognition ... ." (yadvișayā buddhir na vyabhicarati, tat sat, yadvișayā vyabhicarati, tad asat, iti sadasadvibhāge buddhitantre sthite ... BGB, 2.16). "utpādavyayadhrauvyayuktam sat" TAS, 5.29.

21 "ṣaṇnāmapi padārthānām sādharmyamastitvābhidheyatvajñeyatvāni", (VD, p. 13).

“dravyādīnām trayānām api sattāsambandhah", Ibid.

The statement "Whatever is real is momentary" can be called analytic, as it is true by virtue of the definitions of the terms involved in it. This is consistent with one of the formulations of Quinton's (1964, p. 45) analytic necessity that "if necessity depends on meaning it depends on logic and definitions".

Steinkellner (1974, p. 129) regarded the essential properties, namely existence (what I have called realness) and 'having origin', as a pure generic property and particular property where a certain exclusion is referred to, respectively. This does not seem to be correct, as even the 'pure generic property' refers to a certain exclusion. Since every meaningful word refers to the exclusion of what it is not, the word real (sat) cannot be an exception to this rule. 'Sat' would refer to the exclusion of unreal objects, such as God and soul. Secondly, treating different essential properties as on par with each other does not explain why Dharmakīrti took up realness and not either originated-ness or made-ness for analytically deriving momentariness from them.

The Buddhist conception of momentary is more radical than that of the Vaiśeșikas. According to the Buddhists, a momentary thing exists for only one moment. It comes into existence (and that is its moment of existence) and then ceases to exist. According to Vaiīśeșikas, a momentary object exists for two moments. It comes in to existence, stays for a moment and ceases.

That the doctrine of momentariness is not found in the early stage of Buddhism is clearly borne out by Von Rospatt (1995, pp. 14-16). According to him (Ibid., p. 18), the oldest testimony to the theory of momentariness is the Khanikakathā of the Kathāvatthu, where the doctrine is refuted that "all phenomena (dhamma) are as momentary as a single mental entity (ekacittakkhanika)".

Von Rospatt (1998, p. 470) seems to be right when he said “. .. since only advanced yogins seem to have been able to perceive momentariness directly, the soteriological significance of this doctrine remains very limited. This explains why it only played a marginal role in the wider context of Buddhist spirituality". that all conditioned things are unsatisfactory, and in verse 279 it is said that all things are not-self (non-substantial). 
"na svato nāpi parato, na dvābhyāṃ nāpy ahetutaḥ | utpannā jātu vidyante bhāvāh kvacana kecana | I" MMK, 1.3.

"anutpanneșu dharmeșu nirodo nopapadyate", MMK, 1.11ab (Cessation is not tenable with respect to the things which have not arisen).

"prakrtau kasya cāsatyām anythātvam bhaviṣyati I prakrtau kasya ca satyām anyathātvam bhavișati I I MMK, 15.9 (If intrinsic nature is not there, what will undergo change? And if there is an intrinsic nature, what will undergo change?).

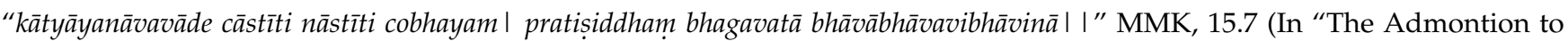
Katyāyana" the venerable one denied both "it exists" and "it does not exist", who clearly perceives the existent and the non-existent). "yad bhūyasā kātyāyana ayam loko'stitām vāa abhinivișto nāstitāṃ ca. tena na parimucyate", PP, p. 118.

“... Sammādițthi sammādițthī”ti bhante vuccati, kittāvatā nu kho bhante sammādițthi hotīti? Dvayamnissito kho'yam kaccāna loko yebhuyyena atthitañceva natthitañca. Lokasamudayañca kho kaccāna yathābhütam sammappaññāya passato yā loke natthitā, sā na hoti. Lokanirodham kho kaccāna yathābhütam sammappaññāya passato yā loke atthitā, sā na hoti. ... ... Ettā̃oatāu kho kaccāna, sammāadițthi hoti. Sabbamatthī'ti kho kaccāna, ayameko anto. Sabbam natthī'ti ayam dutiyo anto. Ete te kaccāna ubho ante anupagamma majjhena tathāgato dhammaṃ deseti ... ", Kaccānagottasutta, SN, p. 17.

For example, Chapters 8 (Karmakärakaparīkșā), 10 (Agnīndhanaparīkṣā), and 20 (Sāmagrīparīkșā).

"tat tat prāpya yadutpannam notpannam tat svabhāvatah", PP, p. 3.

Candrakīrti in PP (pp. 2-3) interprets pratītya as prāpya and prāpya as apeksya.

"asmin satīiam bhavati, hrasve dìrgham yathā sati", PP, p. 3.

43 Hence, the following extreme claim of Kalupahana (2011, pp. 45-46) about the Buddha's approach to truth is not acceptable: "Absolute truths had no place in Buddha's view of experience and reason ... The explanation of experience and reason left no room for a sharp dichotomy between the true and the false" etc. Would not the statement "Everything conditioned is impermanent" be absolutely true (or timelessly true) according to the Buddha?

44 The argument advanced here is continuous with my other paper, "Essentialism, Eternalism and Buddhism", see Gokhale (1996). I had made a distinction there between svabhāvavāda in a logical sense and in a metaphysical sense. The distinction is parallel to the one I am making here: logico-linguistic essentialism and ontological essentialism.

\section{References}

Barnhard, Franz, ed. 1965. Udānavarga. Göttingen: Vandenhoeck \& Ruprecht.

Bronkhorst, Johannes. 2009. Buddhist Teaching in India; Boston: Wisdom Publications. Available online: https:/ /www.academia.edu/32 88020 / BuddhistTeachinginIndia (accessed on 5 December 2021).

Buddharakkhita, Acharya. 1985. The Dhammapada: The Buddha's Path of Wisdom. Kandy: Buddhist Publication Society.

Davids, T. W. Rhys, and J. Estlin Carpenter, eds. 1995. The Dīghanikāya. Oxford: Pali Text Society, vol. II.

Dhammajoti, Kuala Lumpur. 2009. Sarvāstivāda Abhidharma. Hong Kong: Centre of Buddhist Studies, The University of Hon Kong.

Feer, M. Leon, ed. 1994. Samyutta Nikaya of Sutta Pitaka. London: Pali Text Society.

Gokhale, Pradeep P. 1992. Inference and Fallacies Discussed in Ancient Indian Logic with Special Reference to Nyāya and Buddhism. Delhi: Sri Satguru Publications.

Gokhale, Pradeep P. 1996. Essentialism, Eternalism and Buddhism. In Buddhism in India and Abroad. Edited by Kalpakam Sankarnarayan, Motohiro Yoritomi and Shubhada A. Joshi. Mumbai: Somaiya Publications.

Gokhale, Pradeep P. 1997. Hetubindu of Dharmakīti: A Point on Probans. Delhi: Satguru Publication.

Gokhale, Pradeep P. 2018. The concept of necessity in Dharmakīti's theory of inference. Jadavpur Journal of Philosophy 27: 2017-18.

Gombrich, Richard F. 2011. How Buddhism Began, 2nd ed. London: Routledge.

Gombrich, Richard F. 2013. What the Buddha Thought. Sheffield: Equinox.

Hayes, Richard P. 1987. On the reinterpretation of Dharmakīrti's svabhāvahetu. Journal of Indian Philosophy 15: 319-32. [CrossRef]

Humphreys, Christmas, ed. 1987. The Wisdom of Buddhism. New Delhi: Promilla and Company Publishers.

Kalupahana, David J. 2011. A History of Buddhist Philosophy: Continuities and Discontinuities. Delhi: Motilal Banarsidass.

Lysenko, V. G. 2016. Atomistic approach in the Buddhist Abhidharma schools: Atoms and dharmas (Atomisticheskii podkhod v shkolah buddiiskoi Abhidharmy: Dharmy i atomy). Voprosy Filosofii 8: 150-165. (In Russian).

Mehendale, K. C., ed. 1893. The Tarkasamgraha with the Dīpikäby Annambhatța. Bombay: Mrs. Radhabai Atmaram Sagoon.

Oldenberg, Hermann, ed. 1879. Vinayapitakam. London: Williams and Norgate, vol. I.

Pandeya, Ram Chandra, ed. 1989. The Pramānavārtikam of Ācārya Dharmakìrti. Delhi: Motilal Banarsidass.

Pradhan, P., and K. P. Jayaswal, eds. 1967. Abhidharmakośabhāsya of Vasubandhu. Patna: Research Institute.

Quinton, Anthony. 1964. The A-priori and the analytic. Proceedings of the Aristotelian Society 64: 31-54. [CrossRef]

Steinkellner, E. 1974. On the interpretation of the svabhāvahetu. Wiener Zeitschrift für die Kunde Südasiens 18: 117-29.

Tatia, Natmal. 2007. Umāsvāti's/Umāsvāmin's Tattvārthasütra: What There Is. Delhi: Motilal Banarsidass.

Vaidya, P. L., ed. 1960. Madhyamakaśāstra of Nāgāriuna, with the Commentary, Prasannapadā by Candrakìrti. Darbhanga: The Mithila Institute of Darbhanga.

Shrikrishnashastri, ed. 1890. Vaiśeșikadarśanam of Kanāda with Praśastapādabhāṣam (Śaka: 1812). Mumbai: Nirnay Sagar Press. 
Von Rospatt, Alexander. 1995. The Buddhist Doctrine of Momentariness: A Survey of the Origins and Early Phase of This Doctrine Up to Vasubandhu. Stuttgart: Franz Steiner Verlag.

Von Rospatt, Alexander. 1998. Momentariness, Buddhist doctrine of. In Routlege Encyclopedia of Philosophy. Edited by Edward Craig. New York: Routledge, vol. VI, pp. 469-73.

Warren, Henry Clarke. 1953. Buddhism in Translations. Passages Selected from the Buddhist Sacred Books and Translated from the Original Pali Into English. Cambridge: Harward University Press.

Warrier, A. G. Krishna, trans. 1983, Bhagavadgītābhāṣya of Śri Śañkarācārya. With text and English Translation. Madras: Sri Ramkrishna Math. 